\title{
Student Perceptions Of Peer Credibility Based On Email Addresses
}

\author{
Jeffrey A. Livermore, Henry Ford Community College, USA \\ Marla G. Scafe, Walsh College, USA \\ Linda S. Wiechowski, Walsh College, USA \\ David J. Maier, Henry Ford Community College, USA
}

\begin{abstract}
The purpose of this study was to evaluate students' perceptions of their peer's credibility based on email addresses. The survey was conducted at a community college in Michigan where all students were registered and actively taking at least one course. The survey results show that a student's selection of an email address does influence other students' perception of their credibility. An email address that consists of a nickname reduces the student's perception of peer credibility.
\end{abstract}

Keywords: Student Credibility; Email Address; Peer Credibility; Online Education

\section{INTRODUCTION}

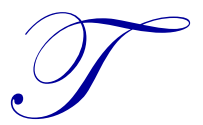

here is a growing trend toward online education. Schools find that there is a financial incentive and students appreciate the convenience and freedom of not being tied to set class times and locations. One of the challenges of online education is that students may never meet their peers and only have contact with them through an electronic learning management system. Online students complete group assignments and may even be asked to assess the course work of their peers. Some students question the credibility of their peers' ability to perform in these roles (Kaufman \& Schunn, 2011). Students who perceive that they are in online groups with students of lesser abilities may become discouraged (Ge, 2011).

Credibility is an important factor in post-secondary education. Credibility is influenced by a number of factors including ethnicity, gender, sexual orientation, and choice of clothing (Morris, Gorham, Cohen \& Huffman 1996; Patton 1999; Russ, Simonds, \& Hunt 2000). Russ, Simonds, and Hunt have proposed that marginalized status may be a factor in how a faculty member's credibility is perceived by students (Russ, Simonds, \& Hunt 2000).

Interaction between faculty and student and student to student is important to the learning process. With the growth of online and web-assisted education, more interaction is taking place asynchronous through chat rooms, discussion boards, and email. The establishment of a learning community enhances the learning process. Placing students in virtual teams for group assignments and group discussions helps promote the collaborative learning process in an online or web-enhanced environment (Palloff \& Praff, 2001).

While the students are often given the opportunity to work asynchronously using a school's online technology, they often use their personal or work email instead. The purpose of this study is to evaluate students' perceptions of their classmate's credibility based on the email address they use for communication.

\section{LITERATURE REVIEW}

The use of online technology in the classroom is changing the way college professors teach their courses. Online technology is used not only in online and web-assisted courses, but often in face-to-face courses as well. While an entirely online course is typically administered through a learning management system (LMS), webassisted courses may rely on a school's website, portal or email system rather than an LMS. With many LMS's, 
student-to-student interaction takes place in discussion boards, chats, or an LMS email system. Often, student usernames are designated by the LMS (as defined by the school), and in some form, consists of the student's first and last name. However, students will often use their own personal email address rather than the email address defined by the LMS or school. The use of a personal email address has several potential problems in terms of student identity, confidentiality, and credibility.

First, an instructor may not know the identity of the person sending an email from outside the school defined email system. A potential FERPA violation exists if an instructor communicates confidential information with a student using the student's personal email address or work email address (NACE 2008). Also, a 2011 study found that a student's use of a personal email address may negatively impact how a faculty member perceives the student's credibility (Livermore, Wiechowski \& Scafe, 2011). It is important that email communication between faculty and students take place in either the school's email system or LMS.

Student to student interaction is vital to the learning process (Palloff \& Pratt, 1999). Any lack of credibility between students may hamper the learning particularly in an online or web-assisted setting. Several researchers have studied student perceptions and interactions in online courses and have found that interaction is a critical factor in the learning process (Picciano, 2002; Schmieder, 2008; Liu 2008; Gibson, \& Blackwell 2005; Schultz, Schultz, \& Henkel 2005).

It is important for students to consider the email name they use in their communication with their classmates. Newman, Hebein, and Drost found that a standard business email address was considered more acceptable than using a nickname for an email address (Newman, Hebein \& Drost 2008).

The purpose of this study is to evaluate students' perceptions of their classmates based on email addresses. Since more and more communication between students is taking place remotely, this is becoming more of a concern to the learning community.

\section{METHOD}

In setting up this research project, the username and mail service provider were the independent variables and the perceived credibility was the dependant variable. The following research hypotheses were evaluated:

H1: Student perception of student classmate credibility will be impacted by the domain name used in the email address

H2: Student perception of student classmate credibility will be impacted by the nicknames in the username

To test these hypotheses, a survey was created with the SurveyMonkey tool and placed online for three months from November 2011 through January 2012. Invitations to take the survey were sent to 340 students enrolled in fully online sections of introductory computer courses at Henry Ford Community College. Henry Ford Community College is a community college in a western suburb of Detroit.

To eliminate gender and name bias, the survey only referred to male names and used the most popular names. The names used were a combination of the most popular first and surnames according to two different sources. The three most popular American surnames were once Smith, Johnson, and Brown (Barker, 1926). According to the Social Security Administration, two of the most popular male first names in 2011 were Michael and Ethan (SSA 2011).

\section{SURVEY}

The students responded to the following survey questions:

- You are enrolled in an online section of the "Introduction to Technology" course that is a requirement for your major field of study. You have never met any of the other students enrolled in your section and are 
unlikely to meet them in the future. You have been assigned to work with another student on a group project. All that you know about this student is their e-mail address. Based on the e-mail address of MrBaseball@EDS.com, how credible do you feel that your fellow student is? Please rate the student on a scale that ranges from not credible to extremely credible (not credible, credible, extremely credible, no opinion).

- You are enrolled in an online section of the "Introduction to Technology" course that is a requirement for your major field of study. You have never met any of the other students enrolled in your section and are unlikely to meet them in the future. You have been assigned to work with another student on a group project. All that you know about this student is their e-mail address. Based on the e-mail address of Michael.Johnson@AOL.com, how credible do you feel that your fellow student is? Please rate the student on a scale that ranges from not credible to extremely credible. (not credible, credible, extremely credible, no opinion).

- You are enrolled in an online section of the "Introduction to Technology" course that is a requirement for your major field of study. You have never met any of the other students enrolled in your section and are unlikely to meet them in the future. You have been assigned to work with another student on a group project. All that you know about this student is their e-mail address. Based on the e-mail address of Ethan.Brown@HFCC.edu, how credible do you feel that your fellow student is? Please rate the student on a scale that ranges from not credible to extremely credible. (not credible, credible, extremely credible, no opinion).

- You are enrolled in an online section of the "Introduction to Technology" course that is a requirement for your major field of study. You have never met any of the other students enrolled in your section and are unlikely to meet them in the future. You have been assigned to work with another student on a group project. All that you know about this student is their e-mail address. Based on the e-mail address of Michael.Johnson@EDS.com, how credible do you feel that your fellow student is? Please rate the student on a scale that ranges from not credible to extremely credible. (not credible, credible, extremely credible, no opinion).

- You are enrolled in an online section of the "Introduction to Technology" course that is a requirement for your major field of study. You have never met any of the other students enrolled in your section and are unlikely to meet them in the future. You have been assigned to work with another student on a group project. All that you know about this student is their e-mail address. Based on the e-mail address of Ethan.Brown@EDS.com, how credible do you feel that your fellow student is? Please rate the student on a scale that ranges from not credible to extremely credible. (not credible, credible, extremely credible, no opinion).

- You are enrolled in an online section of the "Introduction to Technology" course that is a requirement for your major field of study. You have never met any of the other students enrolled in your section and are unlikely to meet them in the future. You have been assigned to work with another student on a group project. All that you know about this student is their e-mail address. Based on the e-mail address of Michael.Johnson@HFCC.edu, how credible do you feel that your fellow student is? Please rate the student on a scale that ranges from not credible to extremely credible. (not credible, credible, extremely credible, no opinion).

- You are enrolled in an online section of the "Introduction to Technology" course that is a requirement for your major field of study. You have never met any of the other students enrolled in your section and are unlikely to meet them in the future. You have been assigned to work with another student on a group project. All that you know about this student is their e-mail address. Based on the e-mail address of MrBaseball@AOL.com, how credible do you feel that your fellow student is? Please rate the student on a scale that ranges from not credible to extremely credible. (not credible, credible, extremely credible, no opinion).

- You are enrolled in an online section of the "Introduction to Technology" course that is a requirement for your major field of study. You have never met any of the other students enrolled in your section and are unlikely to meet them in the future. You have been assigned to work with another student on a group project. All that you know about this student is their e-mail address. Based on the e-mail address of Ethan.Brown@AOL.com, how credible do you feel that your fellow student is? Please rate the student on a scale that ranges from not credible to extremely credible. (not credible, credible, extremely credible, no opinion). 
- You are enrolled in an online section of the "Introduction to Technology" course that is a requirement for your major field of study. You have never met any of the other students enrolled in your section and are unlikely to meet them in the future. You have been assigned to work with another student on a group project. All that you know about this student is their e-mail address. Based on the e-mail address of MrBaseball@HFCC.edu, how credible do you feel that your fellow student is? Please rate the student on a scale that ranges from not credible to extremely credible. (not credible, credible, extremely credible, no opinion).

\section{RESULTS}

The following scenarios were presented to students to rate their fellow students' credibility based on students' email addresses:

\section{Scenario \#1: Mr. Baseball@EDS.com}

Thirty students rated this email as not credible and 53 students rated it as Neither possessing nor lacking credibility. Only 12 students rated it as Credible and 2 students rated it as Extremely credible. The Chi-square Goodness of Fit test showed a Chi-square value of 62.0515, which was significant at both the .05 and .01 levels of significance $(\mathrm{p}=.000)$.

\section{Scenario \#2: Michael.Johnson@AOL.com}

Eight students rated this email address as not credible with 34 students rating it as Neither possessing nor lacking credibility. Thirty-seven students rated it as Credible with 7 students rating it as Extremely credible. The Chi-square Goodness of Fit test showed a Chi-square value of 21.2632, which was significant at both the .05 and .01 levels of significance $(\mathrm{p}=.000)$.

\section{Scenario \#3: Ethan.Brown@HFCC.edu}

Only 2 students rated this email as not credible, while 24 rated it as extremely credible and 43 rated it as credible. Twenty-two students rated it as neither possessing credibility nor lacking credibility. The Chi-square Goodness of Fit test showed a Chi-square value of 37.0440, which was significant at both the .05 and .01 levels of significance $(\mathrm{p}=.000)$.

\section{Scenario \#4: Ethan.Brown@EDS.com}

This was the same user name but a different domain name. Only 7 students rated this email as extremely credible versus 24 in the previous email address. Forty-one students rated it as credible and 35 rated it as neither possessing nor lacking credibility. Ten students rated it as not credible versus only 2 in the previous email address. The Chi-square Goodness of Fit test showed a Chi-square value of 38.3978, which was significant at both the .05 and .01 levels of significance $(\mathrm{p}=.000)$.

\section{Scenario \#5: Michael.Johnson@HFCC.edu}

Nineteen students rated this email address as extremely credible and 37 rated it as credible, not quite as much as Ethan.Brown@HFCC.edu but more credible than Michael.Johnson@AOL.com . Only 2 students rated it as not credible and 22 rated it as neither possessing nor lacking credibility. The Chi-square Goodness of Fit test showed a Chi-square value of 30.9 , which was significant at both the .05 and .01 levels of significance $(\mathrm{p}=.000)$. When this user name was used with AOL.com, the credibility ratings were much lower.

\section{Scenario \#6: Mr.Baseball@AOL.com}

Only 3 students rated this email address as extremely credible and only 18 students rated it as credible. Twenty-three students rated it as not credible and 44 rated it as neither possessing nor lacking credibility. This was 
one of the lowest ratings of all scenarios. The Chi-square Goodness of Fit test showed a Chi-square value of 39.1818 , which was also significant at both the .05 and .01 levels of significance $(\mathrm{p}=.000)$.

\section{Scenario \#7: Ethan.Brown@AOL.com}

Only 3 students rated this email as extremely credible, like the Mr. Baseball email address above, however, more students (27) rated it as credible, compared to the Mr. Baseball email address above. Nine students rated it as not credible and 44 students rated it as neither possessing nor lacking credibility. The Chi-square Goodness of Fit test showed a Chi-square value of 49.7711, which was also significant at both the .05 and .01 levels of significance $(\mathrm{p}=.000)$. This was one of the largest Chi-square values, showing the largest disparity in ratings amongst students.

\section{Scenario \#8: Mr.Baseball@HFCC.edu}

Seven students rated this email as extremely credible and 18 students rated it as credible. This email faired much better, and was rated more credible than Mr.Baseball@EDS.com and Mr.Baseball@AOL.com. Eighteen students rated it as not credible because of the user name and 41 rated it as neither possessing nor lacking credibility. The Chi-square Goodness of Fit test showed a Chi-square value of 29.2381, which was also significant at the .05 and .01 levels of significance $(\mathrm{p}=.000)$.

Here is a break-down or side-by-side comparison of email addresses:

- $\quad$ Mr.Baseball@AOL.com was least credible

- $\quad$ Mr.Baseball@EDS.com was more credible

- $\quad$ Mr.Baseball@HFCC.edu was the most credible of these three but not as credible as a regular male surname as user name

- $\quad$ Michael.Johnson@AOL.com was more credible than Mr. Baseball

- $\quad$ Michael.Johnson@ HFCC.edu was more credible than Michael.Johnson@AOL.com

- $\quad$ Ethan.Brown@ AOL.com was more credible than Mr. Baseball but least credible of the Ethan Browns

- $\quad$ Ethan.Brown@EDS.com was more credible than Ethan.Brown@ AOL.com

- $\quad$ Ethan.Brown@HFCC.edu was the most credible of all addresses

Conclusions are to use professional or regular surnames, not nicknames and use college email address not common or professional ones for most credibility. It is seen as more credible than work email addresses.

Gender was investigated and shown to not produce significant differences in the students' ratings, with a Chi-square of $4.2737, \mathrm{p}=.153$.

Employment, whether currently employed or unemployed showed no significant differences in the students' ratings as well, with a Chi-square of 3.49296, $\mathrm{p}=.174$.

\section{CONCLUSION}

It has been found at Henry Ford Community College that a student's email address is an important factor when students determine the credibility of their peers. Students taking online courses should be aware that their credibility in group work is being judged in part by their e-mail address. Students that want to be taken seriously or develop a reputation for leadership should select an appropriate e-mail address and provider for educational purposes.

\section{AUTHOR INFORMATION}

Jeffrey A. Livermore, Ph.D., is an Associate Dean at Henry Ford Community College. In addition to his administrative duties, he teaches Information Assurance and is currently researching the ethics and pedagogy of teaching Information Assurance. E-mail: jlivermo@walshcollege.edu 
Marla G. Scafe, Ph.D., has been a faculty member at Walsh College for over 25 years teaching Quantitative Methods and Research at the undergraduate, masters, and doctoral levels. She has also been a consultant-evaluator for the Higher Learning Commission of North Central Association for over 15 years. Her research interests center around the use of group testing with adult learners. E-mail: mscafe @ walshcollege.edu (Corresponding author)

Linda S. Wiechowski, Ph.D., earned a bachelor degree in accounting from Walsh College. She also holds a Masters in Business Administration and a PhD in Economics, both from Wayne State University. She has been teaching finance and economics courses at Walsh College for over 20 years. Her research interests include a variety of corporate finance topics, health economics, and the integration of online technology in all levels of education. She has presented "Best Practices in Online Education" at a variety of conferences. E-mail: lwiechow@walshcollege.edu

David J. Maier, Ph.D. is a lead instructor at Henry Ford Community College. He teaches in the CIS program. David is completed a survey book on Web development.

\section{REFERENCES}

1. $\quad$ Barker, H. (1926), Our leading surnames. American Speech. 1(9), 470-477.

2. Gibson, J., \& Blackwell, C. (2005) Heading for cyberspace: planning a strategy for success with online classes. Journal of College Teaching \& Learning (2)10, 7-12.

3. Kaufman, J. \& Schunn, C. (2011). Student's perceptions about peer assessment for writing: their origin and impact on revision work. Instructional Science. 39(3), 387-406.

4. Liu, S. (2008) Student interaction experiences in distance learning courses a phenomenological study, Online Journal of Distance Learning Administration, (11)1. retrieved September 2012, http://www.westga.edu/ distance/ojdla/spring111/Liu111.html

5. Livermore, J., Scafe, M., \& Wiechowski, L. (2011) Faculty perceptions of student credibility based on email addresses. Contemporary Issues in Education Research, (4)3, 19-24.

6. Morris, T., Gorham, J., Cohen, S. \& Huffman, D. (1996). Fashion in the classroom: Effects of attire on student perception of Instructors in college classes. Communication Education. 45(2), 135-148.

7. NACE (2008) FERPA Primer: The Basics and Beyond. Retrieved September, 2012 from http://www.naceweb.org/public/ferpa0808.htm

8. Newman, E., Hebein, F. \& Drost, D. (2008). The perception of an email name. International Journal of Global Business and Economics, Vol. 1, No. 1.

9. Palloff, R. M., \& Pratt, K. (1999). Building learning communities in cyberspace: Effective strategies for the online classroom. San Francisco, CA: Jossey-Bass Inc.

10. Palloff, R. M., \& Pratt, K. (2001). Lessons from the cyberspace classroom: The realities of online teaching. San Francisco, CA: John Wiley \& Sons, Inc.

11. Patton, T. (1999). Ethnicity and gender: An examination of its impact on instructor credibility in the university classroom. Howard Journal of Communication. 10(2), 123-144.

12. Picciano, A., (2002). Beyond student perceptions: issues of interaction, presence, and performance in an online course, Journal of Asynchronous Learning Networks, (6)1, 21-40.

13. Russ, T., Simonds, C., \& Hunt, S. (2002). Coming out in the classroom...An occupational hazard?: The influence of sexual orientation on teacher credibility and perceived student learning. Communication Education. 31(3), 311-324.

14. Schmieder, E., (2008) Communication: The tool to interact with and control your online classroom environment, International Journal of Instructional Technology \& Distance Learning, (5)3, retrieved September 2012, http://www.itdl.org/Journal/Mar_08/article03.htm

15. Schultz, J., Schultz, M. \& Henkel, T. (2005) Determining which delivery styles are best suited for instructing in the distance learning environment, Journal of College Teaching \& Learning (2)11, 61-68.

16. SSA (2008, May 19). Popular Baby Names. Retrieved July, 2008 from http://www.ssa.gov/OACT/babynames/ 